\title{
ANALISIS PENERAPAN HYBRID CONTRACT PADA PRODUK UNIT LINK DI ASURANSI JIWA PT PRUDENTIAL PAMEKASAN
}

\author{
Subairi \\ Institut Agama Islam Negeri Madura \\ Email: subairisyamsuri@gmail.com
}

\begin{abstract}
The study of insurance in Islamic law is a new thing, and has never been found in classical fiqh literature. The discussion of insurance in the area of Islamic sciences only appeared at the stage of the birth of contemporary scholars. Included in relation to the application of hybrid contracts in insurance. Along with the development of life insurance products, insurance companies not only provide traditional insurance services that are purely protection, but also provide various supporting services for financial planning in the future, according to their needs and financial capabilities, whether they are personal, family or group. one service offered is a combination of insurance and investment, known as Unit Link. The application of a hybrid contract on the unit link in Prudential Pamekasan life insurance is a contract between a participant and a sharia insurance company using a tijarah contract called wakalah bil ujrah, and an easyarabah / musyarakah contract on its investment. and covenants among participants using the tabarru contract 'in the form of a grant, and Qard. The advantages and disadvantages of implementing Unit Link hybrid contracts at PT Prudential Pamekasan syariah and conventional can be seen from the reasons customers choose insurance and the most influential is the rate of premium returns and the investment returns, in this case PRUsyariah is relatively smaller than conventional. 3). The implementation of the Prudential PRUlink Pamekasan hybrid contrac Unit Link in the perspective of Islamic economics can produce multiple legal interpretations between those who allow and those who do not.
\end{abstract}

Keywords: Hybrid Contract, Unit Link. Life insurance.

\begin{abstract}
Abstrak
Kajian asuransi dalam hukum Islam merupakan hal baru, dan belum pernah di temukan dalam literatur-literatur figh klasik. Pembahasan asuransi dalam wilayah kajian ilmu-ilmu keislaman baru muncul pada fase lahirnya ulama kontemporer. Termasuk dalam kaitannya dengan penerapan hybrid contract pada asuransi. Seiring dengan berkembangnya produk asuransi jiwa, perusahaan asuransi tidak hanya menyediakan layanan asuransi tradisional yang hanya murni pada proteksi, namun juga menyediakan berbagai layanan penunjang untuk merencanakan keuangan di masa depan, yang sesuai dengan kebutuhan dan

Ulumuna: Jurnal Studi Keislaman

Vol.6 No.1 : Juni 2020

P-ISSN 2442-8566

E-ISSN 2685-9181
\end{abstract}


kemampuan finansialnya, baik pribadi, keluarga maupun kelompok, salah satu layanan yang ditawarkan adalah penggabungan antara asuransi dan investasi atau yang dikenal dengan Unit Link. Penerapan hybrid contract pada pada unit link di asuransi jiwa Prudential Pamekasan adalah akad antara peserta dan perusahaan asuransi syariah menggunakan akad tijarah yang disebut wakalah bil ujrah, dan akad mudaharabah/musyarakah pada investasinya. dan akad sesama peserta menggunakan akad tabarru' berupa hibah, dan Qard. Kelebihan dan kekurangan penerapan hybrid contract Unit Link di PT Prudential Pamekasan syariah maupun konvensional dapat dilihat alasan nasabah memilih asuransi dan yang paling berpengaruh adalah tingkat pengembalian premi beserta hasil investasinya dalam hal ini PRUsyariah relatif lebih kecil dari konvensioanal. 3). Penerapan bybrid contrac Unit Link Prudential PRUlink Pamekasan dalam perspektif ekonomi Syariah dapat menghasilkan multi tafsir hukum antara yang memperbolehkan dan yang tidak.

Kata kunci: Hybrid Contract, Unit Link. Asuransi Jiwa.

\section{Pendahuluan}

Kajian asuransi dalam hukum Islam merupakan hal baru, dan belum pernah di temukan dalam literatur-literatur fiqh klasik. Pembahasan asuransi dalam wilayah kajian ilmu-ilmu keislaman baru muncul pada fase lahirnya ulama kontemporer. Tercatat dalam literatur sederatan nama yang menekuni kajian asuransi diantaranya adalah, Ibnu Abidin (1784-1836), Muhammad Nejatullah al-Siddiqi, Muhammaad Muslehuddin, Fazlur Rahman, Mannan, yusuf Qardawi,. Moh. Ma'shum Billah, merupakan deretan nama ulama ternama yang hidup di era modern. Di sisi lain, kajian tentang asuransi merupakan sebuah paket dari kajian ekonomi Islam yang biasanya selalu dikaji bersama-sama dengan pembahasan perbankan Islam. Jadi asuransi Islam atau asuransi syariah merupakan hasil pemikiran ulama kontemporer. ${ }^{1}$

Pada realitanya dalam kehidupan sehari-hari manusia dihadapkan dengan berbagai ketidakpastian, berbagai risiko, dan berbagai kemungkinankemungkinan buruk yang akan terjadi, seperti sakit, terkena cacat, atau penyakit kritis, dan bahkan meninggal dunia, atau lanjut usia (ketidakpastian kapan seseorang meninggal dunia menyebabkan hidup terlalu lama dan adanya keterbatasan dalam mencari nafkah). sebagai seorang Muslim kita perlu tawakkal

\footnotetext{
${ }^{1}$ Andri soemitro Dr,. M.A. Bank Dan Lembaga Kenangan Syariah, Jakarta, (Prenada Media Group, 2009), 248

111 | Ulumunâ: Jurnal Studi Keislaman
} 
atau pasrah terhadap segala kemungkinan tersebut, namun kita harus juga antisipasi dengan ikhtiar untuk meminimalisir kemungkinan kerugian financial yang akan kita hadapi ketika mengalami musibah-musibah tersebut.

Seiring dengan berkembangnya produk asuransi jiwa, perusahaan asuransi tidak hanya menyediakan layanan asuransi tradisional yang hanya murni pada proteksi, namun juga menyediakan berbagai layanan penunjang untuk merencanakan keuangan di masa depan, yang sesuai dengan kebutuhan dan kemampuan finansialnya, baik pribadi, keluarga maupun kelompok, salah satu layanan yang ditawarkan adalah penggabungan antara asuransi dan investasi atau yang dikenal dengan Unit Link. Dengan membeli produk unit link, nasabah tidak lagi direpotkan antara asuransi dan investasi, nasabah akan mendapatkan investasi dan proteksi sekaligus. Tidak perlu repot repot lagi, karena semuanya dalam satu paket.

Unit Link sendiri sudah mulai di operasikan oleh berbagai perusahaan asuransi salah satunya adalah PRULink atau Prudential Unit Link. Sejak peluncuran produk asuransi terkait investasi (unit link) pertamanya di tahun 1999, Prudential Indonesia telah menjadi pemimpin pasar untuk kategori produk tersebut di Indonesia. Prudential Indonesia menyediakan berbagai produk dan layanan yang dirancang untuk memenuhi dan melengkapi setiap kebutuhan keuangan para nasabahnya di Indonesia. ${ }^{2}$

Tentang penerapan akad ganda atau bybrid contract yang ada pada Unit Link Syariah yaitu ketika peserta membayar kontribusi maka model akad yang diterapkan adalah akad ijarah dengan wakalah bil ujrah, dan sebagian dari kontribusi yang di investasikan, dan dari hasil investasi yang diperoleh peserta sepakat untuk membayar iuran tabarru' dan akad yang diterapkan berupa akad tabarru' berupa akad hibah. Dan ini adalah konsekuensi dari unit link karena merupakan penggabungan dari asuransi dan investasi maka akadnya pun menerapkan model akad berganda atau bybrid contract.

Namun dalam kajian fiqh penerapan akad-akad dalam unit link perlu kajian khusus dan mendalam karena model penerapannya menggunakan bydrid contrac atau al-Uqud al-Maliyah al-Murakkabah antara Tabarru' dan Tijarah. Penggabungan antara akad yang berorientasi pada taawwun nonprofit dengan akad yang berorientasi pada profit atau keuntungan. Adanya penggabungan

${ }^{2}$ Data ini diperoleh dari Profil Company perusahaan asuransi Prudential yang dipublis di www.prudential.ac.id

Vol.6 No. 1 Juni $2020 \mid 112$ 
kedua akad ini terindikasi adanya ketidaksesuaian dengan kajian hukum ekonomi syariah.

Berangkat dari pemaparan di atas, serta melihat realitas penawaran jasa asuransi jiwa unit link di Pamekasan Madura ini perlu ada penelitian khusus terkait dengan penerapan bybrid contract di Unit Link khususnya Prudential di Pamekasan dalam perspektif ekonomi syariah, mengingat mayoritas penduduk Pamekasan adalah Muslim, hal ini peneliti lakukan untuk menganalisa terkait dengan akad-akad unit link ini serta kesesuainnya dengan ekonomi syariah, mengingat asuransi merupakan masalah ijtihadiyah yang hukummnya pun perlu dikaji sedalam mungkin karena tidak dijelaskan secara eksplisit oleh al-Quran maupun as-Sunnah, dan keberadaanya pun tidak terlepas dari perbedaan pandangan ulama-ulama modern.

Untuk menjawab permasalahan dalam penelitian ini, maka rancangan penelitian ini adalah menggunakan kualitatif dengan pendekatan studi kasus yang pengumpulan datanya melalui wawancara mendalam, observasi, dan dokumentasi. Dalam metode kualitatif ini, peneliti memaparkan data dari hasil wawancara mendalam, observasi, dan dokumentasi yang dilakukan di tempat penelitian.Responden dalam penelitian ini adalah owner perusahaan dalam hal ini Agency Manager, seniur unit manager, unit manager, dan tenaga pemasaran, serta Nasabah, PT Prudential Pamekasan Madura.

\section{Penerapan hybrid contract pada Unit Link di asuransi jiwa Prudential Pamekasan}

Penerapan akad yang diterapkan dalam asuransi jiwa Prudential Pamekasan adalah dengan menerapkan al-Uqud al-Maliyah al-Murakkabah yaitu tabarru' dan tijarah, penerapan kedua akad ini akan selalu melekat pada Unit Link Prudential Pamekasan, karena unit link itu sendiri adalah penggabungan antara asuransi dan investasi, proses hubungan peserta dan perusahaan dalam mekanisme pertanggungan pada asuransi syariah adalah shering of risk atau saling menanggung risiko, apabila terjadi musibah maka semua peserta asuransi syariah saling menanggung lewat akad tabarru' yang berupa bibah, sedangkan peranan perusahaan asuransi terbatas hanya pemegang amanah dalam mengelola dan menginvestasikan dana kontribusi peserta. Oleh karena itu dana-dana yang terhimpun harus di kelola secara baik, baik dari segi administratif maupun investasinya, pada saat peserta memberikan kuasa kepada perusahaan untuk bertindak sebagai operator dan administrator dan disitulah terjadi akad tijarah 113 | Ulumunâ: Jurnal Studi Keislaman 
yang berupa akad wakalah bil ujrah. Dengan demikian penerapan bybrid contract itu diterapkan dalam asuransi jiwa unit link Prudential Pamekasan, dalam kajiannya perlu untuk melihat proses penerapan dari penggabungan dua akad antara tabarru' dan tijarah, apakah orientasi awal dari akad tersebut apakah dari akad yang transaksinya bersifat mencari keuntungan (akad tijarah), kemudian di ikuti akad yang transaksinya tidak mencari keuntungan (akad tabarru') atau sebaliknya, karena semua akad dalam bybrid contract tersebut mempunyai konsekuensi hukum dalam perspektif ekonomi Syariah.

Bahwa dalam asuransi syariah maupun konvensional terdapat kelebihan dan kekurangan, dalam pelaksanaanya asuransi syariah menerapkan sistem saling berbagi risiko atau sharing risk antara peserta sehingga tercipta ladang amal untuk saling tolong menolong atau taawnn, dengan memberikan dana bibah kepada sesama peserta jika terkena musibah, dengan seperti itu ada kepuasan tersendiri karena selalu bisa beramal dan berderma, sedangkan dalam asuransi konvensional dalam pelaksanaannya dengan mengalihkan risiko atau transfer risk. kepada perusahaan, sehingga premi yang masuk sepenuhnya dikelola perusahaan, dan perusahaan yang bertanggung jawab jika terjadi klaim kepada nasabah.

Antara konvensional dan syariah terdapat beberapa kelebihan dan kekurangan, yang pertama dalam asuransi syariah nasabah dapat keunggulan dengan menjalankan asuransi syariah dapat memperkokoh keimanan kita terhadap agama kita, karena dengan demikian kita berusaha menjalankan ajaran syariah secara kaffah, sehingga kita merasa lebih tentram dan tenang, serta berusaha segala sesuatu yang dilarang agama seperti riba, maysir, gharar, dll. Yang kedua kelebihan asuransi syariah dalam proses menjalankan kegiatan asuransi kita bisa membantu saudara kita dengan cara berderma lewat rekening tabarru' yang ada dalam iuran nasabah atau peserta. Adapun kekurangan dari asuransi syariah ini adalah dalam sisi keuangan baik dalam klaim rumah sakit dan keuntungan investasi relatif lebih rendah daripada konvensioanl. Dan ini juga yang menjadi kelebihan asuransi Prudential Pamekasan konvensional. 


\section{Penerapan hybrid contract pada Unit Link di asuransi jiwa PT. Prudential Pamekasan dalam perspektif ekonomi Syariah}

Ketika dikaitkan dengan akad yang ada pada asuransi jiwa unit link Prudential Pamekasan dalam perspektif ekonomi syariah, maka dapat menghasilkan analisis yang multitafsir hal tersebut disebabkan karena beberapa hal sebagai berikut:

a.Penerapan multi akad yang ada pada asuransi jiwa unit link Prudential Pamekasan antara Tabarru' dan Tijarah menghasilkan dua opsi hukum yang pertama, jika penerapan kedua akad antara tijarah dan qard ini saling bergantung antara satu sama yang lain maka penerapan akad tijarah dengan tabarru'berupa akad qard ini tidak diperbolehkan, sebagaimana dalam hadits,

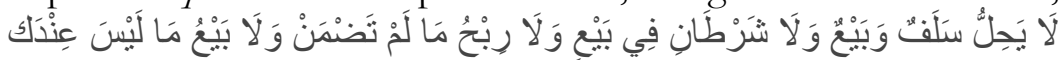
"Tidak halal menjual sesuatu dengan syarat memberikan butang, dan tidak, halal dua syarat dalam satu transaksi, dan tidak halal keuntungan menjual sesuatu yang belum engkau jamin, serta tidak halal menjual sesuatu yang bukan milikmu." K

Pengertian salaf dalam hadis di atas adalah qard. sesungguhnya mensyaratkan akad jual beli dalam akad qard akan mengantarkan terhadap ziadah atau riba, karena qard itu akan memberikan manfaat dan qard yang memberikan manfaat itu disebut riba. Terkecuali penerapan kedua akad ini tidak muallaq (tidak bergantung antara satu dengan yang lain). sebagaimana keterangan yang peneliti peroleh dalam kitab al-Uqud al-Maliyah alMurakkabab. ${ }^{3}$

Opsi yang kedua, jika penerapan kedua akad antara akad tijarah berupa wakalah bil ujrah dan tabarru' berupa hibah maka itu di perbolehkan, karena tinjauan manfaat dari ijarah tersebut bukan diperoleh dari hibah tersebut, melainkan dari jasa perusahaan karena membantu mengelola dana dari nasabah tersebut, dan atas jasanya tersebut perusahaan mendapat fee atau Ujrah, melalui biaya wakalah yang di ambil perusahaan di dasarkan dengan unsur keridlaan/kerelaan dari nasabah. Sebagaiamana firman Allah dalam al-QS. An-Nisa' ayat 29: yang artinya: 'Hai orang-orang yang beriman, janganlah kamu saling memakan harta sesamamu dengan jalan yang batil, kecuali dengan jalan perniagaan yang berlaku dengan suka sama suka di antara kamu. dan janganlah kamu membunub dirimu, sesunggubnya Allah adalab Maba Penyayang kepadamu”. Sesungguhnya saling ridha ini adalah syarat utama kecuali saling

${ }^{3}$ Keterangan tersebut peneliti dapatkan dalam kitab al-Uqud al-Maliyah al-Murakkabah. Hal.97 115 | Ulumunâ: Jurnal Studi Keislaman 
ridha, jika sudah terjadi unsur keridlaan antara kedua orang yang bertransaksi di dalam tijarah ini maka halal lah transaksi tijarah tersebut dengan dalil al-Quran tersebut di atas, kecuali tijarah yang diharamkan, seperti transaksi khamr dll. ${ }^{4}$

b.Penerapan antara akad tabarru' berupa akad qard, serta tabarru' beruapa hibah, penerapan tabarru' di Prudential Pamekasan tidak hanya berupa hibah tapi juga akad qard, dimana qard dalam Prudential ini di berikan apabila dana tabarru' yang berupa hibah tidak mencukupi untuk membayarkan klaim, maka peserta bisa meminjam dana kepada operator tanpa dikenakan bunga. Pinjaman ini diperoleh dari dana yang tersedia pada dana cadangan hasil pembagian dari 30\% surplus shering. Akad yang digunakan untuk pinjaman ini adalah akad Qard. Penerapan multi akad antara tabarru' berupa bibah dan tabarru' berupa qard ini di perbolehkan selama qard yang di transaksikan tidak mendatangkan manfaat bagi pihak yang menyediakan qard, karena qard yang mensyaratkann sesuatu yang mendatangakan manfaat itu tidak diperbolehkan.

\section{Penerapan hybrid contract pada Unit Link di asuransi jiwa PT. Prudential Pamekasan}

Berdasarkan dari hasil temuan penelitian, dapat dijelaskan bahwa, Kontrak atau akad yang digunakan pada asuransi syariah yang melibatkan hubungan antara pemegang polis/peserta satu dengan yang lain adalah akad tabarru'. Dalam akad tabarru' ini peserta memberikan bibah yang akan digunakan untuk menolong dan membantu peserta lain yang terkena musibah. Sedangkan perusahaan asuransi hanya bertindak sebagai pengelola dana hibah saja. Sifat dari akad tabarru' yang di laksanakan dalam asuransi jiwa Prudential Pamekasan adalah karena sebagai berikut:

a. Antar pemegang polis/peserta yang satu dengan yang lain saling menanggung risiko yang ada atau yang terjadi

b. Setiap pemegang polis/peserta akan melakukan pembayaran hibah dan juga menerima hibah/bantuan dan saling membagi risiko, inilah yang disebut sebagai konsep shering of risk (saling menanggung risiko).

c. Sifat akadnya tidak bertujuan komersial (mencari keuntungan)

\footnotetext{
${ }^{4}$ Keterangan tersebut peneliti dapatkan dalam kitab al-Uqud al-Maliyah al-Murakkabah, 72
} Vol.6 No. 1 Juni $2020 \mid 116$ 
Sedangkan dari kontrak atau akad tijarah, akad tijarah ini digunakan pada transaksi yang melibatkan hubungan antara pemegang polis/peserta dengan perusahaan asuransi yang berfungsi melaksanakan tugas-tugas operasioanal dan administrasi pada perusahaan asuransi itu sendiri. Dalam akad tijarah ini, perusahaan asuransi bertindak sebagai pengeloola (mudharib) dan peserta bertindak sebagai pemegang polis (shobibul mal).

Adapun sifat dari akad tijarah dalam pelaksanaannya pada asuransi jiwa ini adalah sebagai berikut:

a. Perusahaan asuransi syariah berperan sebagai underwriter (penilai risiko), collector (pengumpul iuran-iuran tabarru), dan fund manager (penegelola dana investai peserta).

b. Perusahaan asuransi syariah bukan pemilik dana kontribusi/premi dari peserta, tetapi perusahaan asuransi syariah hanya bertindak sebagai pemegang amanah dalam mengelola dana tersebut.

c. Perusahaan asuransi syariah akan menerima biaya pengelolaan (management fee) dari fungsinya sebagai administrator/pengelola.

d. Begitu pula perusahaan asuransi syariah akan memperoleh bagi hasil atau biaya (fee) atas upayanya dalam memaksimalkan dana yang terhimpun dalam dana tabarru' peserta (pool of hibah fund).

Dalam pelaksanaannya akad-akad yang diterapkan oleh asuransi syariah ini menerapkan lebih dari satu akad, dan penerapannya antara satu akad dengan akad yang lain saling berkaitan, antara tabarru' dengan ijarah, kedua akad tersebut diterapkan dalam satu paket asuransi jiwa yang berbasis Unit Link, hal inilah yang disebut bybrid contract atau al-Uqud al-Maliyah al-Murakkabah. Dari pemaparan di atas dapat di ringakas bahwa pelaksanaan bybrid contract yang ada pada Prudential Pamekasan menggunakan akad tabarru' pada transaksi antara pemegang polis atau peserta. Dan akad tijarah pada transaksi antara pemegang polis dengan Prudential Pamekasan dan nama akadnya adalah akad wakalah bil ujrah akad ini digunakan yang berkaitan penerimaan biaya pengelolaan ataupun yang berkaitan dengan pengelolaam investasi. Penggunaan akad-akad ini dalam satu transaksi atau produk asuransi perlu ada kajian khusus mengingat ada ketentuan hukum dalam penerapan bybrid contract dalam ekonomi Syariah, dalam hal ini akan dijelaskan pada fokus penelitian yang ketiga, untuk dianalisis dengan ekonomi Syariah. 


\section{Kelebihan dan kekurangan hybrid contract Unit Link Prudential Pamekasan baik Syariah maupun Konvensional}

Dalam pelaksanaannya setiap kegiatan asuransi jiwa yang berbasis unit link khususnya di Prudential Pamekasan baik syariah dan konvensional mempunyai kelebihan dan kekurangan masing-masing dalam setiap produknya. Pada saat pengajuan untuk menjadi nasabah di Prudential Pamekasan produk yang biasa digunakan adalah PRUlink assurance account untuk konvensional dan PRUlink syariah assurance account (PAA). PRUlink assurance account itu adalah produk unit link dengan premi berkala di mana nasabah dapat memilih kombinasi antara kebutuhan proteksi dan investasi dalam satu polis. Premi berkala dapat dibayarkan sampai usia 99 tahun. Terdapat kelebihan dalam PAA ini mengapa Prudential Pamekasan menerapkan PAA ini baik Syariah maupun Konvensional.

a. Perhitungan biaya asuransi berdasarkan usia tertanggung pada saat masuk. Berbeda dengan produk tradisional yang menghitung biaya asuransi dari awal tahun hingga kontrak berakhir, pada PAA biaya asuransi dihitung berdasarkan usia tertanggung pada saat masuk. Dengan demikian semakin muda usia seseorang ketika masuk pada program PAA, maka semakin murah biaya biaya asuransi yang akan dikenakan.

b. Nilai tunai (cash velue) dapat dimonitor melalui harga unit. Setiap setoran premi/kontribusi pada PAA akan dialokasikan ke dalam satuan unit. Nasabah dapat memonitor nilai tunai yang dimilikinya pada produk PAA hanya dengan melihat harga unit yang diterbitkan setiap hari di harian Bisnis Indonesia. Koran tempo, dan kontan, serta situs Prudential Indonesia (www.prudential.co.id)

c. Transparan, Nasabah dapat mengetahui kemana dana mereka diinvestasikan sehingga dapat memilih jenis dana investasi yang dikehendaki sesuai dengan profil risiko serta tujuan investasi mereka.

d. Fleksibel. Nasabah dapat melakukan penambahan dana (top up), perubahan penempatan premi/kontribusi dana investasi (redirection), pengalihan dana Investasi (switching), dan Penarikan Dana Investasi (withdrawal) kapan saja sesuai kebutuhan mereka.

Namun dalam pelaksanaannya, asuransi Prudential Pamekasan meskipun produknya sama menggunakan PAA dan pilihan investasinya pun sama menggunakan Equity Fund, tapi presentase jumlah nasabah $80 \%$ lebih memilih konvensional dan 20\% memilih Syariah. 
Ada baberapa alasan mengapa nasabah memilih konvensional dari pada syariah yang pertama, berdasarkan dari hasil wawancara dan observasi serta dokumentasi dari peneliti, hasil dari investasi yang yang ada pada konvensional lebih besar dari pada yang syariah, hal tersebut disebabkan beberapa hal berikut, terkait dengan PAA antara konvensional dan syariah ada perbedaan, untuk konvensional setelah nasabah membayar premi, tahun pertama dikenakan biaya akuisisi $100 \%$ sehingga tidak ada saldo investasi yang terbentuk di tahun pertama, di tahun kedua premi yang disetor dikenakan biaya akuisisi sebesar $60 \%$ dari premi yang disetor, sementara sisa $40 \%$ di alokasikan sebagai unit investasi, kemudian di tahun ketiga dari premi yang disetor dikenakan biaya akuisisi sebesar $15 \%$ dari premi yang disetor, sementara sisanya $85 \%$ dari premi yang disetor dialokasikan sebagai unit investasi, di tahun ke empat dikenakan biaya akuisisi $15 \%$ sementara $85 \%$ dari premi yang disetor dialokasikan sebagai unit investasi, dan pada tahun ke enam dan seterusnya sampai tabun ke sepulub premi yang disetor langsung $100 \%$ dari premi tersebut di alokasikan sebagai unit investasi.

Tabel 4.2 Alokasi premi PAA konvensional: ${ }^{5}$

\begin{tabular}{|l|l|l|l|l|l|l|}
\hline PREMI & $\begin{array}{l}\text { Tahun } \\
\text { Ke-1 }\end{array}$ & $\begin{array}{l}\text { Tahun } \\
\text { Ke-2 }\end{array}$ & $\begin{array}{l}\text { Tahun } \\
\text { Ke -3 }\end{array}$ & $\begin{array}{l}\text { Tahun } \\
\text { Ke-4 }\end{array}$ & $\begin{array}{l}\text { Tahun } \\
\text { Ke-5 }\end{array}$ & $\begin{array}{l}\text { Tahun } \\
\text { Ke-6 atas }\end{array}$ \\
\hline Berkala & $0 \%$ & $40 \%$ & $85 \%$ & $85 \%$ & $85 \%$ & $100 \%$ \\
\hline
\end{tabular}

Adapun pada PAA Syariah, alokasi kontribusi tahun pertama dan tahun kedua sudah tersedia sebesar masing-masing $20 \%$, dan biaya wakalah pada dua tahun pertama menjadi $80 \%$. Hal ini karena pada asuransi syariah, dana tabarru' tidak diperbolehkan pada posisi kosong sehingga untuk menutupi jika terjadi risiko, maka dana untuk pembayaran klaim sudah tersedia. Namun pada tahin ketiga hingga ke lima, alokasi premi PAA Syariah tetap sama seperti PAA konvensional, yaitu alokasi kontribusi untuk investasi sebesar $85 \%$, dan biaya wakalah menjadi 15\%. Demikian juga sejak tahun keenam dan seterusnya, alokasi kontribusi untuk investasi sepenuhnya ditempatkan pada investasi, sama dengan ketentuan PAA konvensional.

Tabel 4.3 Alokasi Kontribusi PAA Syariah: ${ }^{6}$

\footnotetext{
${ }^{5}$ PRU Sales Academy, 62

${ }^{6}$ PRU sales academy, 97

119 | Ulumunâ: Jurnal Studi Keislaman
} 


\begin{tabular}{|l|l|l|}
\hline Tahun kontribusi & Alokasi (\%) & Biaya Wakalah (\%) \\
& & \\
\hline Tahun 1-2 & $20 \%$ & $80 \%$ \\
\hline Tahun 3-5 & & \\
& $85 \%$ & $15 \%$ \\
\hline k ke atas & & \\
& & \\
\hline
\end{tabular}

Dari pemaparan di atas dapat diketahui adannya ketidaksamaan biaya akuisisi ataupun biaya wakalah sehingga menyebabkan hasil yang berbeda pula dalam hal keuntungan sisi investasinya, namun meskipun keuntuangan relatif lebih kecil sebagai masyarakat Muslim diharapakan mampu melek terhadap keuangan Islam khusunya dalam asuransi jiwa syariah sebagai pilihan sebagai jaminan untu proteksi diri dan keluarganya. Azaz yang mendasari asuransi syariah adalah azaz jaminan bersama, sehingga dengan menggunakan jasa asuransi syariah diharapkan dapat menghindari kegiatan-kegiatan yang menyalahi perinsip syariah, seperti Gharar, Riba, Maysir. Yang sangat merugikan terhadap masyarkat luas, dengan perinsip asuransi syariah dapat memperkuat tali ukhuwah islamiyah antara kaum muslimin dengan mengikatkan lewat perinsip asuransi syariah yaitu, tanggung jawab bersama, saling membantu dan bekerjasama, dan perlindungan bersama. 
Dalam hal ini, Perinsip dasar asuransi syariah ini ada sepuluh macam, yaitu: tauhid, keadilan, tolong-menolong, kerja sama, amanah, kerelaan, larangan riba, larangan maysir, dan larangan gharar. ${ }^{7}$ Dengan demikian diharapkan adanya asuransi syariah tidak sebatas alternatif pilihan tapi bisa tumbuh dan berkembang di Prudential Pamekasan.

\section{Penerapan hybrid contract pada Unit Link di asuransi jiwa PT. Prudential Pamekasan dalam perspektif ekonomi Syariah}

Sebagaimana dijelaskan sebelumnya bahwa dalam pelaksanaannya asuransi jiwa Prudential Pamekasan yang berbasis unit link itu menggunakan beberapa jenis akad yaitu akad antara sesama pemilik polis/peserta menggunakan akad tabarru' yang disebut bibah. Dan kemudian akad antara pemilik polis/peserta dengan perusahaan asuransi syariah menggunakan akad tijarah yang disebut wakalah bil ujrah. Penerapan beberapa akad dalam satu transaksi atau yang dikenal dengan bybrid contract ini terdapat ketentuanketentuan yang harus di patuhi sebagai suatu konsekuensi hukum syariah, perlu diketahui bahwa setiap kontarak atau akad yang transaksinya tidak bersifat mencari keuntungan (akad tabarru') dan ingin di ubah bentuk kontraknya menjadi kontrak yang bersifat mencari keuntungan (akad tijarab), maka hal ini tidak dapat dilakukan dan tidak dapt diperbolehkan. Hal ini Sebagaimana yang dikemukakan oleh Adiwarman Karim dalam buku Bank Islam Analisis Fiqh dan Keuangan.

Skema tabarru':

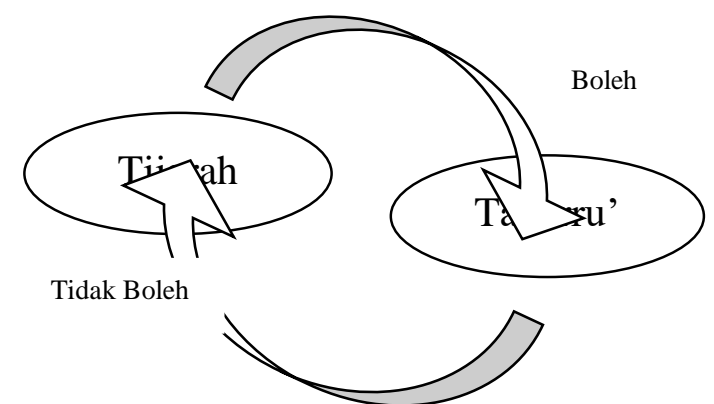

Penjelasan: jika transaksinya dari tijarah pada tabarru' diperbolehkan. Tapi jika dari tabarru' menuju tijarah tidak diperbolehkan.

\footnotetext{
${ }^{7}$ Hasan Ali,.MA, Asuransi dalam perspektif hukum Islam, Jakarta (Pranada Media. Group,2004), 125

$121 \mid$ Ulumunâ: Jurnal Studi Keislaman
} 
Pada dasarnya penerapan bybrid contract ini terdepat perbedan pendapat di kalangan ulama' tentang hukum asal dari bybrid contract ini apakah itu boleh atau tidak, pendapat yang pertama memperbolehkan penerapan bybrid contract sampai ada dalil syar'i yang menunjukkan keharamannya. Dan pendapat ini pendapat mayoritas ulama' hanafiyah, madhzab maliki, syafi'e, dan hanbali. Dan pendapat yang kedua tidak memperbolehkan penerapan bybrid contract, atau batal transaksinya, sampai ada dalil syar'i yang menunjukkan kebolehannya. Dan pendapat ini adalah ad-Drabiriyah. ${ }^{8}$

Sesungguhnya Allah memerintahkan untuk menyempurnakan atau memenuhi segala transaksi atau akad, dan dalil ini umum mencakup semua akad, dan tidak menghususkan terhadap satu akad, dengan demikian dalil ini menunjukkan sesungguhnya hukum asal dari setiap akad itu diperbolehkan. ${ }^{9}$ Adapun pendapat yang kedua yang tidak memperbolehkan bybrid contract ini adalah firman Allah swt QS. Al-Baqarah ayat 229:

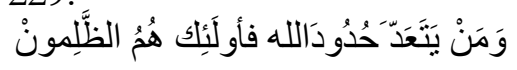

Artinya "Barangsiapa yang melanggar bukum-bukum Allah, maka janganlah melanggarnya. Barangsiapa yang melanggar bukum-bukum Allab mereka itulah orangorang yang dzalim."

Sesungguhnya syarat-syarat dan akad-akad yang tidak disyariatkan maka yang melaksanaknnya adalah melanggar hukum-hukum Allah dan ziyadah (menambahi hukum dalam agama yang sudah sempurna sebagaimana Qs AlMaidah Ayat 3). Maka dengan demikian menunjukkan sesungguhnya hukum asal dalam bybrid contract ini adalah tidak diperbolehkan. ${ }^{10}$

Meskipun terdapat perbedaan pada hukum dasar bybrid contract ini, namun pelaksanaannya memiliki batasan tersendiri baik yang memperbolehkan ataupun yang tidak, batasan tersebut dapat dilihat dari penjelasan yang ada, meskipun diperbolehkan ada batasan antara akad apa saja yang boleh digabung, dan akad apa saja yang tidak boleh, begitu juga sebaliknya. Ketika dikaitkan dengan akad yang ada pada asuransi jiwa unit link Prudential Pamekasan dalam perspektif ekonomi syariah, maka dapat menghasilkan analisis yang multitafsir hal tersebut disebabkan karena beberapa hal sebagai berikut:

a. Penerapan multi akad yang ada pada asuransi jiwa unit link Prudential Pamekasan antara Tabarru' dan Tijarah menghasilkan dua opsi hukum

\footnotetext{
${ }^{8}$ Abdurrahman an-Najdi,terjemah dari buku Abkamul Uqud al-Almaliyah al-Murakeabah, 69

${ }^{9}$ Abdurrahman an-Najdi,terjemah dari buku Abkamul Uqud al-Almaliyah al-Murakekabah, .71

${ }^{10}$ Abdurrahman an-Najdi,terjemah dari buku Abkamul Uqud al-Almaliyah al-Murakekabah, 70
}

Vol.6 No. 1 Juni $2020 \mid 122$ 
yang pertama, jika penerapan kedua akad antara tijarah dan qard ini saling bergantung antara satu sama yang lain maka penerapan akad tijarah dengan tabarru' berupa akad qard ini tidak diperbolehkan, sebagaimana dalam hadits,

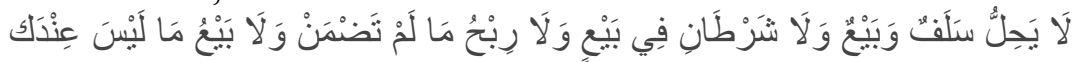

"Tidak balal menjual sesuatu dengan syarat memberikan butang, dan tidak balal dua syarat dalam satu transaksi, dan tidak halal keuntungan menjual sesuatu yang belum engkau jamin, serta tidak halal menjual sesuatu yang bukan milikemu."

Pengertian salaf dalam hadis di atas adalah qard. sesungguhnya mensyaratkan akad jual beli dalam akad qard akan mengantarkan terhadap ziadah atau riba, karena qard itu akan memberikan manfaat dan qard yang memberikan manfaat itu disebut riba. Terkecuali penerapan kedua akad ini tidak muallaq (tidak bergantung antara satu dengan yang lain). sebagaimana keterangan yang peneliti peroleh dalam kitab al-Uqud al-Maliyah al-Murakkabah. ${ }^{11}$

Opsi yang kedua, jika penerapan kedua akad antara akad tijarah berupa wakalah bil ujrah dan tabarru' berupa hibah maka itu di perbolehkan, karena tinjauan manfaat dari ijarah tersebut bukan diperoleh dari hibah tersebut, melainkan dari jasa perusahaan karena membantu mengelola dana dari nasabah tersebut, dan atas jasanya tersebut perusahaan mendapat fee atau Ujrah, melalui biaya wakalah yang di ambil perusahaan di dasarkan dengan unsur keridlaan/kerelaan dari nasabah.

Sesungguhnya saling ridha ini adalah syarat utama kecuali saling ridha, jika sudah terjadi unsur keridlaan antara kedua orang yang bertransaksi di dalam tijarah ini maka halal lah transaksi tijarah tersebut dengan dalil al-Quran tersebut di atas, kecuali tijarah yang diharamkan, seperti transaksi khamr dll. ${ }^{12}$

b. Penerapan antara akad tabarru' berupa akad qard, serta tabarru' beruapa hibah, penerapan tabarru' di Prudential Pamekasan tidak hanya berupa hibah tapi juga akad qard, dimana qard dalam Prudential ini di berikan apabila dana tabarru' yang berupa hibah tidak mencukupi untuk membayarkan klaim, maka peserta bisa meminjam dana kepada

\footnotetext{
${ }^{11}$ Keterangan tersebut peneliti dapatkan dalam kitab al-Uqud al-Maliyah al-Murakkabah. 97

${ }^{12}$ Keterangan tersebut peneliti dapatkan dalam kitab al-Uqud al-Maliyah al-Murakkabah,72 $123 \mid$ Ulumunâ: Jurnal Studi Keislaman
} 
operator tanpa dikenakan bunga. Pinjaman ini diperoleh dari dana yang tersedia pada dana cadangan hasil pembagian dari 30\% surplus shering. Akad yang digunakan untuk pinjaman ini adalah akad Qard. Penerapan multi akad antara tabarru' berupa bibah dan tabarru' berupa qard ini di perbolehkan selama qard yang di transaksikan tidak mendatangkan manfaat bagi pihak yang menyediakan qard, karena qard yang mensyaratkann sesuatu yang mendatangakan manfaat itu tidak diperbolehkan.

\section{Kesimpulan}

Penerapan multi akad pada unit link syariah adalah akad pada transaksi antara pemegang polis/peserta asuransi syariah adalah akad tabarru'berupa akad hibah, dan Qard, sedangkan akad pada transaksi antara pemegang polis/peserta asuransi syariah dengan perusahaan asuransi dan reasuransi syariah adalah akad tijarah, dan nama akadnya adalah wakalah bil wirah baik untuk akad yang berkaitan dengan penerimaan biaya pengelolaan (management fee) ataupun yang berkaitan dengan pengelolaan investasi. Kelebihan dan kekurangan hybrid contract unit link di PT Prudential Pamekasan antara Konvensional dan Syariah. Azaz yang mendasari asuransi syariah adalah azaz jaminan bersama, sehingga dengan menggunakan jasa asuransi syariah diharapkan dapat menghindari kegiatan-kegiatan yang menyalahi perinsip syariah, seperti Gharar, Riba, Maysir. Yang sangat merugikan terhadap masyarkat luas, dengan perinsip asuransi syariah dapat memperkuat tali ukhuwah islamiyah antara kaum muslimin dengan mengikatkan lewat perinsip asuransi syariah yaitu, tanggung jawab bersama, saling membantu dan bekerjasama, dan perlindungan bersama dan ini menjadi kelebihan asuransi syariah. Adapun kekurangan asuransi syariah di bandingkan konvensioanal meskipun sama-sama menggunakan PAA (PRUlink assurance account) hasil investasi yang syariah relatif lebih kecil di bandingkan yang konvensional dan ini juga menjadi kelebihan di konvensioanl, dan sangat berpengaruh terhadap calon nasabah untuk memilih. Penerapan multi akad di unit link Prudential Pamekasan, Pada perinsipnya Akad tabarru' Akad tabarru' adalah semua bentuk kontrak atau akad yang dilakukan dengan tujuan kebaikan dan tolong-menolong, dan bukan semata untuk tujuan komersial (mencari keuntungan). Pada asuransi syariah, akad ini terdapat pada dana kebajikan (tabarru'). Kontrak atau akad tabarru' ini bersifat saling menguntungkan antara kedua belah pihak, dan tidak dipergunakan untuk transaksi-transaksi yang bersifat komersial atau mencari keuntungan. 


\section{Subairi}

\section{Daftar Pustaka}

Abdullah bin Muhammad bin Abdurrahman bin Ishaq Alu Syaikh,. Dr. 2007. Tafsir ibnu Katsir Jilid 4,trejemah, Jakarta: Pustaka Imam Syafi'i.

Ade Arthesa, Edhia Handiman. 2006, Bank \& Lmbaga Keuangan Bukan Bank, Jakarta Indeks Gramedia.

Abdullah Bin Muhammad Bin Abdullah Al-Imroni. 1431 H/2010 M, AlUqud Al-Maliyah Al-Murakkabah, Terj,,Riyadh, Darul Kanuz Sybilia.

Abdurrahman An-Najdi, ahkamul al-Uqud al-Maliyah al-Murakkabah.

Ali, Hasan,.MA, 2004, Asuransi dalam perspektif hukum Islam, Jakarta, Prenada Media, Group.

Arikunto, Suharsimi, 2006, Prosedur Penelitian Jakarta : PT Renika Cipta.

Himpunan Fatwa Keuangan Syariah Dewan Syariah Nasional, Jakarta, Erlangga, 2014

http:/www.duwitmu.com/asuransi/pengertian-unit-link-manfaat-

danimplikasinya/.

Kementrian Agama RI, 1992 Al-Qur'an Transliterasi Perkata dan Terjemah Perkata, Bandung: Jumanatul Ali-ART.

Latunasa, Izzak, 1988, penelitian pendidikan suatu pengantar, Jakarta : Departemen Pendidikan dan Kebudayan.

Majalah Investor edisi 2011

Masrura,Waqiatul, 2011, Kumpulan Ayat dan Hadits Tentang Pendidikan, Pamekasan: STAIN Press.

Moleong, Lexy J. 2000, Metode Penelitian Kualitatif, Bandung: PT. Remaja Rosda Karya.

Munir, Misbahul, 2007. Ajaran-Ajaran Ekonomi Rasulullah Kajian Hadits Nabi Dalam Perspektif Ekonomi. Malang: UIN Maliki Pres. 
Nafikir, Muhammad, 2009, Bursa Efek \& Investasi Syariah. Jakarta, Serambi Ilmu.

Nawawi, Ismail, 2009, Ekonomi Kelembagaan Syariah, Surabaya: putra media Surabaya.

Nor, Dumairi, 2008, Ekonomi Syariah Versi Salaf, Pesuruan; Pustaka Sidogiri.

Nurdiana, Ilfi, 2008. Hadits-hadits Ekonomi, Malang: UIN Maliki Pres.

Shihab, M. Quaraish, 2003. Tafsir al-Misbah. Jakarta, Lentera Hati.

Sigit Triandaru, Totok Budisantoso, 2006, Bank dan Lembaga Keuangan Lainnya edisi 2, Jakarta, Selemba Empat.

Soemitro, Andri, 2009, Bank Dan Lembaga Keuangan Syariah, Jakarta, Prenada Media Group.

Suhendi, Hendi., Prof. Dr, 2010. Fiqh Muamalah, Jakarta; Rajawali Pres.

Sugiono, 2006 Metode Penelitian Pendidikan Kuantitatif, Kualitatif, Dan $R \& D$ Bandung, Alfabeta.

Suprapto, 2003, Metode Riset Aplikasinya dalam Pemasaran(Jakarta : PT. Rineka Cipta.

Syakir Sula, Muhammad, 2004, Asuransi syariah life and general, Jakarta; Gema insane.

ULAR PRUlink 2015 (Unit Link Anual Report)

Wirdia Ningsih, 2005, Bank dan Asuransi Islam di Indonesia Jakarta: Prenada media.

Wirdyaningsih SH,.MH, dkk, 2005. Bank dan Asuransi Islam di Indonesia, Jakarta, Prenada Media, Group

www.prudential.ac.id.

Yuliana, Indah, 2010 Investasi Produk Keuangan Syariah. Malang, UIN Maliki Press. 